\title{
Radiometric Assay for Cytochrome P-450-Catalyzed Progesterone $16 \alpha$-Hydroxylation and Determination of an Apparent Isotope Effect
}

\author{
YOICHI OSAWA AND MINOR J. COON \\ Departments of Biological Chemistry and Pharmacology, Medical School, \\ The University of Michigan, Ann Arbor, Michigan 48109
}

Received December 16, 1986

\begin{abstract}
In the course of studies on the oxygenation of steroids by purified $P-450$ cytochromes, particularly rabbit liver microsomal cytochrome $P-450$ form $3 \mathrm{~b}$, a rapid and reliable radiometric assay has been devised for progesterone $16 \alpha$-hydroxylation. In view of the lack of a commercially available, suitably tritiated substrate, $\left[1,2,6,7,16,17-{ }^{3} \mathrm{H}\right]$ progesterone was treated with alkali to remove the label from potential hydroxylation sites other than the $16 \alpha$ position. The resulting $\left[1,7,16-{ }^{3} \mathrm{H}\right]$ progesterone was added to a reconstituted enzyme system containing cytochrome $P-450$ form $3 \mathrm{~b}, \mathrm{NADPH}$-cytochrome $P-450$ reductase, and NADPH, and the rate of $16 \alpha$-hydroxylation was measured by the formation of ${ }^{3} \mathrm{H}_{2} \mathrm{O}$. This reaction was shown to be linear with respect to time and to the cytochrome $P-450$ concentration. An apparent tritium isotope effect of 2.1 was observed by comparison of the rates of formation of tritium oxide and $16 \alpha$-hydroxyprogesterone, and the magnitude of the isotope effect was confirmed by an isotope competition assay in which a mixture of $\left[1,7,16-{ }^{3} \mathrm{H}\right]$ progesterone and $\left[4-{ }^{14} \mathrm{C}\right]$ progesterone was employed. 1987 Academic Press, Inc.

KEY WORDS: cytochrome $P-450$, rabbit liver form $3 \mathrm{~b}$; progesterone, $16 \alpha$-hydroxylation; liver microsomal hydroxylation reactions; steroid hydroxylation; radiometric enzyme assay; isotope effects.
\end{abstract}

Liver cytochrome $P-450$ mixed-function oxidases are critical components in the metabolism of a variety of xenobiotics as well as endogenous compounds. The multicomponent enzyme system consisting of cytochrome $P-450$, NADPH-cytochrome $P-450$ reductase, and phospholipid requires NADPH and molecular oxygen for catalytic activity (1). Many forms of hepatic microsomal cytochrome $P-450$ have been isolated and characterized, some being inducible and some constitutive $(2,3)$. For example, in the rabbit, phenobarbital, ethanol, and 3-methylcholanthrene induce forms $2,3 \mathrm{a}$, and 4 , respectively $(4,5)$, but no inducers are known for forms 1 and $3 b(6-9)$. The constitutive forms may play an important role in the metabolism of endogenous compounds, but much overlap in substrate preference exists in this family of cytochromes.

The hydroxylation of steroids in various positions has been employed as a probe for the multiplicity of $P-450$ cytochromes as well as to determine the positional and stereochemical specificity of the reaction $(10,11)$. Johnson and co-workers $(9,12-14)$ have used progesterone as a model substrate to study the mechanism of regulation of rabbit liver $P-450$ cytochromes, and our laboratory has undertaken the synthesis of steroidal alkylating agents for use in covalent modification of various forms of cytochrome $P-450$ (15).

In this connection we have developed a rapid and convenient method to assay for steroid hydroxylase activity. We were especially interested in $P-450$ isozyme $3 \mathrm{~b}$ because it exhibits relatively high activity in steroid hydroxylation at the $6 \beta$ and $16 \alpha$ positions. This cytochrome has been reported to be allosterically regulated by certain steroidal effectors, such as $5 \beta$-pregnane- $3 \beta, 20 \alpha$-diol (14). In the present study we describe a rapid 
radiometric assay for progesterone $16 \alpha$-hydroxylase activity involving tritium release to produce tritium oxide. Unlike the previously reported ${ }^{14} \mathrm{C}$-labeled metabolite assay $(12)$, our procedure does not require a time-consuming TLC separation. A simple extraction with activated charcoal was used to remove other radioactive materials from the tritiated water. We have observed an apparent isotope effect of about 2 associated with the $16 \alpha$-hydroxylation of progesterone as measured by tritium release and have verified this effect by an internal competition method. Thus, the assay involving the suitably tritiated progesterone is highly useful when the apparent isotope effect is taken into account.

\section{MATERIALS AND METHODS}

Steroid preparations. $\left[1,2,6,7,16,17-{ }^{3} \mathrm{I}\right]-$ Progesterone $(140 \mathrm{Ci} / \mathrm{mmol})$, synthesized by catalytic reduction of the unsaturated precursor, was purchased from Amersham, $\left[4-{ }^{14} \mathrm{C}\right]$ progesterone $(57 \mathrm{mCi} / \mathrm{nmol})$ was purchased from New England Nuclear, and $6 \beta-$ and $16 \alpha$-hydroxyprogesterone were obtained from Steraloid. $\left[1,7,16-{ }^{3} \mathrm{H}\right]$ progesterone was synthesized by isotopic exchange as follows. $\left[1,2,6,7,16,17-{ }^{3} \mathrm{H}\right]$ Progesterone and $\left[4-{ }^{14} \mathrm{C}\right]-$ progesterone were combined to obtain a mixture with a starting ${ }^{3} \mathrm{H} /{ }^{14} \mathrm{C}$ dpm ratio of 35 and a specific activity of $200 \mu \mathrm{Ci}$ of ${ }^{3} \mathrm{H} / 2.0$ $\mathrm{mg}$ of total steroid in $2.5 \mathrm{ml}$ of $95 \%$ ethanol. The solution was purged with nitrogen, and $0.25 \mathrm{ml}$ of $12 \mathrm{~N} \mathrm{NaOH}$ was added under a nitrogen atmosphere. Aliquots were taken over time, neutralized, taken to dryness under a stream of nitrogen, and counted to monitor the reaction. When the ${ }^{3} \mathrm{H}$ to ${ }^{14} \mathrm{C}$ ratio had leveled off at about 20 , the reaction mixture was placed in a separatory funnel containing $20 \mathrm{ml}$ of benzene, $20 \mathrm{ml}$ of $\mathrm{H}_{2} \mathrm{O}$, and enough concentrated $\mathrm{HCl}$ to bring the $\mathrm{pH}$ to neutrality. The benzene phase was removed, extracted twice with water, and taken to dryness with nitrogen. The resulting progesterone was purified by TLC on silica gel GF (Analtech) in cyclohexane:ethyl ace- tate (2:1). The TLC plates were developed repeatedly until the progesterone spot, as judged by examination under uv light, had moved half way up the plate. The specific activity of all $\left[1,7,16-{ }^{3} \mathrm{H}\right]$ progesterone stock solutions used for assays was determined from the radioactivity and the amount of this compound as measured by its absorbance at $241 \mathrm{~nm}$. The ${ }^{3} \mathrm{H}$ to ${ }^{14} \mathrm{C} \mathrm{dpm}$ ratio was 23 .

Enzyme assays. The enzymatic activity of $P-450$ in catalyzing progesterone $16 \alpha$-hydroxylation was determined by tritium release from this position into the medium. The reaction mixtures contained $0.17 \mu \mathrm{M}$ $P-450$ form 3b, $0.34 \mu \mathrm{M}$ NADPH-cytochrome $P-450$ reductase, $50 \mu \mathrm{g} / \mathrm{ml}$ dilauroylglyceryl-3-phosphorylcholine, $1.0 \mathrm{mM}$ NADPH, $200 \mu \mathrm{M}$ total $1,7,16-{ }^{3} \mathrm{H}-$ and ${ }^{14} \mathrm{C}$ containing progesterone $(97,000 \mathrm{dpm}$ represented by tritium at the $16 \alpha$ position), $50 \mathrm{~mm}$ potassium phosphate buffer, $\mathrm{pH} 7.4$, and $10 \%$ glycerol to improve steroid solubility. The tritiated progesterone was added as an ethanolic solution to a test tube containing the glycerol, and the alcohol was removed under a stream of nitrogen before the addition of the other components. The final volume was $0.6 \mathrm{ml}$, and the reaction mixtures were incubated at $30^{\circ} \mathrm{C}$. The reaction was stopped by the addition of $0.2 \mathrm{ml}$ of $30 \%$ trichloroacetic acid, and then $1.4 \mathrm{ml}$ of a $5 \%$ aqueous suspension of activated charcoal and $0.3 \mathrm{ml}$ of $\mathrm{H}_{2} \mathrm{O}$ were added. The samples were shaken for $30 \mathrm{~min}$ and filtered through cotton-plugged pipets. A $1.7-\mathrm{ml}$ aliquot of the filtrate was removed and neutralized with $\mathrm{NaOH}$, and the radioactivity was measured. Since the substrate contained both ${ }^{3} \mathrm{H}$ and ${ }^{14} \mathrm{C}$ labels, each sample could be monitored for ${ }^{14} \mathrm{C}$ to ensure complete removal of the steroid in this assay for tritium release into the medium. To assay the ${ }^{14} \mathrm{C}$-containing metabolites of progesterone, incubation mixtures were extracted twice with $2 \mathrm{ml}$ of methylene choloride, and the $6 \beta$ - and $16 \alpha$ hydroxyprogesterones formed were separated and purified by the TLC method of Dieter and Johnson (12). 
In the experiments with mouse testicular microsomes, the reaction mixture consisted of $4 \mu \mathrm{M}\left[1,7,16-^{3} \mathrm{H}\right]$ progesterone $\left({ }^{3} \mathrm{H}=6500\right.$ $\mathrm{dpm}), 5 \% \mathrm{Me}_{2} \mathrm{SO}$, microsomes $(0.3 \mathrm{mg}$ of protein $/ \mathrm{ml}$ ), $20 \%$ glycerol, $0.1 \mathrm{mM}$ EDTA,

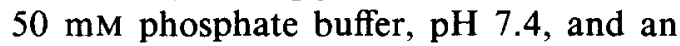
NADPH-generating system composed of 0.5 mM NADP, $20 \mathrm{mM}$ glucose 6-phosphate, 5 $\mathrm{mM} \mathrm{MgCl}_{2}$, and 4 units of glucose-6-phosphate dehydrogenase per milliliter in a total volume of $2.0 \mathrm{ml}$. Incubations were at $37^{\circ} \mathrm{C}$. Reactions were initiated by the addition of the microsomes and stopped by the addition of $\mathrm{NaOH}$ at a final concentration of $0.1 \mathrm{~N}$. The separation of the metabolites, androstenedione, testosterone, and 17-hydroxyprogesterone, was performed according to Malaska and Payne (16) and Quinn and Payne (17).

\section{RESULTS AND DISCUSSION}

Radiometric assay. The measurement of progesterone $16 \alpha$-hydroxylation by the method of tritium release involves the following reaction: $\left[16 \alpha-{ }^{3} \mathrm{H}\right]$ progesterone $+\mathrm{NADPH}+\mathrm{H}^{+}+\mathrm{O}_{2} \rightarrow 16 \alpha$-hydroxyprogesterone $+\mathrm{NADP}^{+}+{ }^{3} \mathrm{H}_{2} \mathrm{O}$. Thus, the tritium released to water is proportional to the amount of $16 \alpha$-hydroxylated steroid formed. The stereochemistry of the reaction was established earlier by the work of Dieter and Johnson (12) with rabbit liver microsomal $P-450$ form $3 b$. Two criteria must be fulfilled for this assay to be valid. First, the appropriately labeled progesterone needs to be radiochemically stable under the assay conditions so that tritium release from position 16 is due only to the action of the $16 \alpha$-hydroxylase, and if other positions of the steroid also contain tritium this radioactive label should not be released enzymatically. Second, the exact amount of tritium at the $16 \alpha$ position must be known.

Since $16 \alpha$-tritiated progesterone was not commercially available, $\left[1,2,6,7,16,17-{ }^{3} \mathrm{H}\right]$ progesterone was treated with alkali to remove the tritium from chemically labile po- sitions. As shown in Fig. 1, the tritium to ${ }^{14} \mathrm{C}$ dpm ratio decreased from 35 to 23 within the first hour and then decreased more slowly to 19 over the next $14 \mathrm{~h}$. In this process tritium is lost due to enolization reactions involving the C-2 and 6 positions, and more rapidly from 2 than 6 , as is typical of $\Delta^{4}$-3-ketosteroids (18). In particular, the removal of the label from position 6 is essential because of the 6-hydroxylase activity of the enzyme. At the end of the alkali treatment the progesterone was purified as described under Materials and Methods and found to have a ${ }^{3} \mathrm{H} /{ }^{14} \mathrm{C}$ dpm ratio of 23 , from which we concluded that the slow phase of tritium loss is due to the formation of degradation products, which were subsequently removed. It should be noted that the theoretical loss in the ratio from 35 to 17.5 would occur only if all positions were tritiated to the same specific activity; Amersham has informed us that this may not be so. Furthermore, losses from enolizable positions may have occurred prior to our experiments.

A portion of the purified, base-exchanged progesterone was treated with perchloric acid for up to 5 days and again purified, and the isotope ratio was again found to remain at

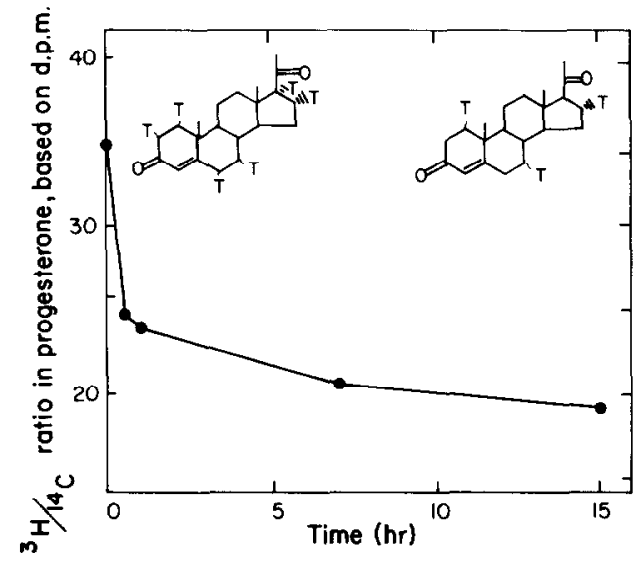

FIG. 1. Time course of conversion of $[1,2,6,7,16,17$ $\left.{ }^{3} \mathrm{H}\right]$ progesterone to $\left[1,7,16-{ }^{3} \mathrm{H}\right]$ progesterone. The starting material was treated with alkali as described under Materials and Methods, and aliquots were taken at intervals for determination of the ${ }^{3} \mathrm{H} /{ }^{14} \mathrm{C} \mathrm{dpm}$ ratio in the steroid. 
23. Since a perchloric acid-catalyzed exchange of the $\mathrm{C}-17$ and $\mathrm{C}-21$ protons of progesterone has been previously established (19), the results confirm the loss at C-17 by alkali treatment. In subsequent studies, described below, direct evidence was obtained to prove the absence of tritium at the $\mathrm{C}-17$ and $6 \beta$ positions.

The exact amount of tritium at the $16 \alpha$ position was determined, as shown in Fig. 2, by treatment of $\left[1,7,16-{ }^{3} \mathrm{H}\right]$ progesterone with mouse testicular microsomes. As indicated, progesterone is converted to testosterone by the action of enzymes present in these microsomes. After incubation for $1 \mathrm{~h}, 75 \%$ conversion to testosterone had occurred with little androstenedione or $17 \alpha$-hydroxypro-
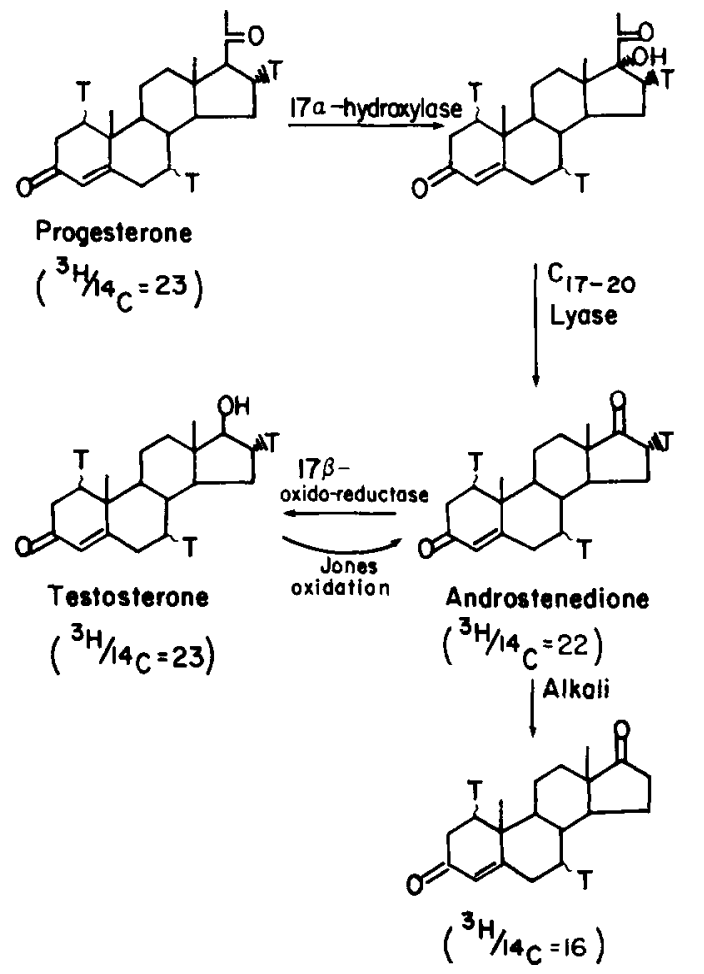

FIG. 2. Conversion of $\left[1,7,16-{ }^{3} \mathrm{H}\right]$ progesterone to $\left[1,7-{ }^{3} \mathrm{H}\right]$ androstenedione. The procedure was as described under Materials and Methods. The ${ }^{3} \mathrm{H} /{ }^{14} \mathrm{C}$ dpm ratio was measured after purification of each steroid. Jones oxidation was performed at $0^{\circ} \mathrm{C}$ according to the method described by Fieser and Fieser (20), and the product was purified by TLC on silica gel GF with cyclohexane:ethyl acetate (2:1).

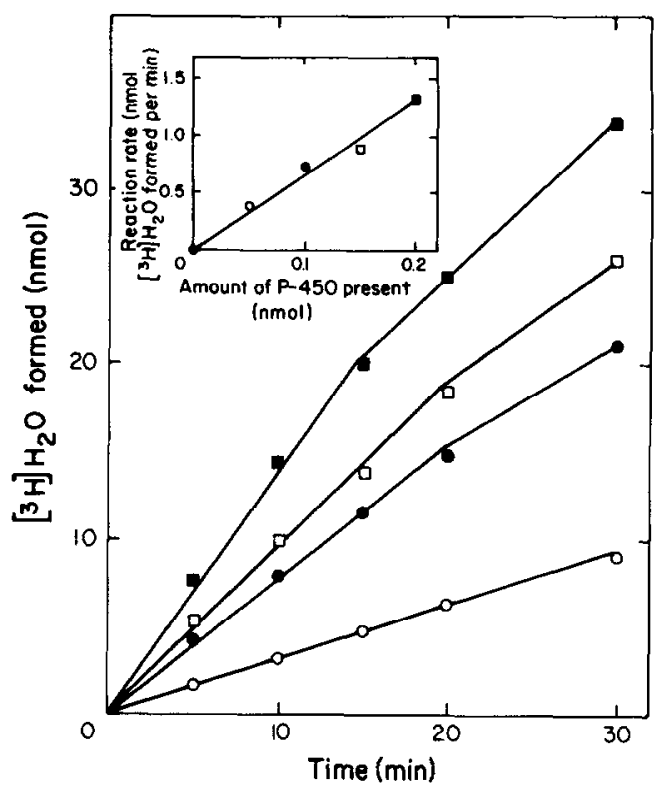

FIG. 3. Kinetics of $P-450$-catalyzed tritium release from $\left[1,7,16 \cdot{ }^{3} \mathrm{H}\right]$ progesterone by cytochrome $P-450$ form $3 \mathrm{~b}$. The assay procedure was as described under Materials and Methods, except that the total volume was $5.1 \mathrm{ml}$, and $0.6-\mathrm{ml}$ aliquots were removed at intervals and assayed for ${ }^{3} \mathrm{H}_{2} \mathrm{O}$. The amount of cytochrome $P-450$ form $3 b$ was varied in different experiments while the $P-450$ to reductase molar ratio was kept constant at 0.5 . The amount of $P-450$ was as follows: $0.05 \mathrm{nmol}, 0 ; 0.10$ $\mathrm{nmol}, \bullet ; 0.15 \mathrm{nmol}, \square$; and $0.20 \mathrm{nmol}, \mathbf{\square}$. The inset shows the results (in the region linear with time) rcplotted to indicate linearity of the assay with respect to the amount of $P-450$ present.

gesterone remaining. The purified testosterone was chemically converted to androstenedione by Jones oxidation (20), and the tritium in the C-16 position of the latter compound, being in an enolizable position, was readily removed by treatment with alkali. A comparison of the ${ }^{3} \mathrm{H} /{ }^{14} \mathrm{C}$ dpm ratios for the starting material and the product, as shown in Fig. 2, reveals that 30\% of the total tritium was originally at the $16 \alpha$ position. It should be noted that tritium was absent from the $16 \beta$ position, since it had been introduced by catalytic reduction. This conclusion was confirmed by Jones oxidation of the enzymatically derived $16 \alpha$-hydroxyprogesterone and by the determination of the ${ }^{3} \mathrm{H} /{ }^{14} \mathrm{C}$ dpm ratio of the product. A pre- 
viously described assay employing this tritium exchange method did not establish the amount of tritium at the $16 \alpha$-position (21). It should also be mentioned that the ${ }^{3} \mathrm{H} /{ }^{14} \mathrm{C}$ dpm ratio of the testosterone (Fig. 2) did not change from that in $\left[1,7,16-{ }^{3} \mathrm{H}\right]$ progesterone; therefore, no tritium was present at the $\mathrm{C}-17$ position.

The amount of ${ }^{3} \mathrm{H}_{2} \mathrm{O}$ formed in the assay for tritium loss from progesterone was linear with time up to $15 \mathrm{~min}$ and with enzyme concentration, as shown in Fig. 3. In other experiments, it was shown that tritium release from the substrate was completely NADPH-dependent. Thus, $\left[1,7,16-{ }^{3} \mathrm{H}\right]$ progesterone is clearly radiochemically stable under the assay conditions.

Apparent isotope effect. In order to validate the assay further and to ensure that ${ }^{3} \mathrm{H}_{2} \mathrm{O}$ formation is a reliable measure of $16 \alpha$-hydroxylation, a comparison was made of tritium release and ${ }^{14} \mathrm{C}$-labeled $16 \alpha$-hydroxyprogesterone formation in the same reaction mixture, as shown in Fig. 4. The formation of each of the two products was directly proportional to the length of the incubation up to $20 \mathrm{~min}$. However, the rate of $16 \alpha$-hy-

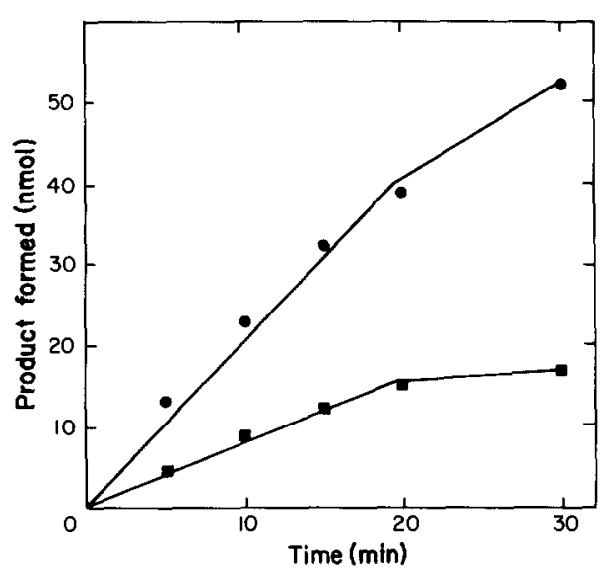

FIG. 4. Comparison of tritium released and 16 $\alpha$-hydroxyprogesterone formed. Aliquots of $0.6 \mathrm{ml}$ each were taken over time from a starting reaction mixture with a volume of $5.1 \mathrm{ml}$ and assayed for the level of tritium in the water and for the amount of ${ }^{14} \mathrm{C}$-labeled $16 \alpha$-hydroxyprogesterone formed. ${ }^{3} \mathrm{H}_{2} \mathrm{O}, \mathbf{0} ; 16 \alpha$-hydroxyprogesterone, 0 .

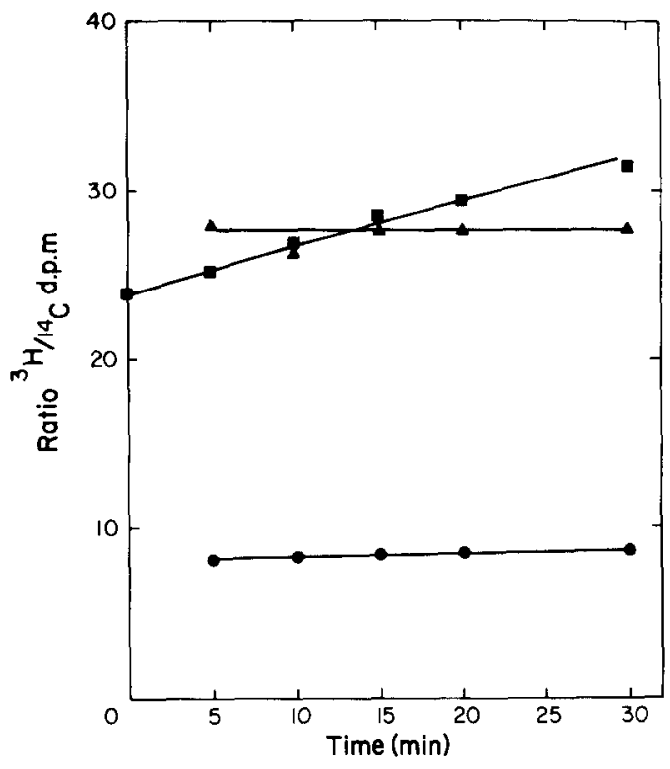

FIG. 5. Isotope competition assay. The experimental conditions for the assay of progesterone hydroxylation were as described under Materials and Methods. The following ${ }^{14} \mathrm{C}$-labeled compounds were isolated: $6 \beta$-hydroxyprogesterone, $\boldsymbol{\Delta} ; 16 \alpha$-hydroxyprogesterone, $\bullet$; and progesterone, $\boldsymbol{n}$. The ratio of ${ }^{3} \mathrm{H} /{ }^{14} \mathrm{C}$ dpm was measured after the purification of each compound by TLC.

droxyprogesterone production $(20.9 \mathrm{nmol} /$ $\mathrm{min} / \mathrm{nmol} P-450)$ was much greater than that of tritium release $(7.9 \mathrm{nmol} / \mathrm{min} / \mathrm{nmol}$ $P-450)$. Since this 2.6 -fold difference in the rates cannot be attributed to the nature of the assays, the results are due to an apparent isotope effect.

The occurrence of an isotope effect was verified with the use of an isotope competition assay. $\left[1,7,16-{ }^{3} \mathrm{H}\right]$ Progesterone $\left({ }^{3} \mathrm{H} /{ }^{14} \mathrm{C}\right.$ $=23$ ) was incubated with $P-4503 \mathrm{~b}$ as already described, and aliquots were taken from the reaction mixture over time and the steroids present were isolated. The ${ }^{3} \mathrm{H} /{ }^{14} \mathrm{C}$ dpm ratios are shown in Fig. 5. The $6 \beta$-hydroxylation of progesterone caused an apparent slight increase in the isotope ratio as compared to that of the starting progesterone. The lack of tritium loss verified the absence of tritium in that position. In contrast, as expected, 16 $\alpha$-hydroxylation resulted in a large decrease in the ratio because of tritium loss to water. The ${ }^{3} \mathrm{H} /{ }^{14} \mathrm{C} \mathrm{dpm}$ ratio in the 
remaining progesterone increased with time, thus indicating tritium enrichment of the substrate, as anticipated if tritiated progesterone is hydroxylated at a slower rate than unlabeled progesterone. Although this is an indication of an isotope effect, the magnitude can be measured with greater precision by direct determination of the larger change of the ${ }^{3} \mathrm{H} /{ }^{14} \mathrm{C}$ ratio in the $16 \alpha$-hydroxysteroid. If $\left[1,7,16-{ }^{3} \mathrm{H}\right]$ progesterone (with $30 \%$ of the total tritium at the $16 \alpha$ position) were to be hydroxylated at the $16 \alpha$ position with loss of that tritium, the ${ }^{3} \mathrm{H} /{ }^{14} \mathrm{C}$ dpm ratio should decrease by $30 \%$, or from 24 to 16.8 . The actual ratio obtained was 8.1 , which indicates the magnitude of the isotope effect to be 2.1. This value correlates with the difference in the observed rates of ${ }^{3} \mathrm{H}_{2} \mathrm{O}$ and ${ }^{14} \mathrm{C}$ labeled $16 \alpha$-hydroxyprogesterone formation. Therefore, tritium release is a valid assay for progesterone $16 \alpha$-hydroxylation when corrected for the apparent isotope effect. Experiments with liver microsomes from untreated rabbits gave similar results, with an apparent isotope effect of about 2 (data not shown).

These apparent isotope effects are in the same range as those observed for 19-hydroxylation of androstenedione catalyzed by the aromatase in human placental microsomes (22), but are much lower than the value of 11.2 reported for this reaction catalyzed by the 19-hydroxylase $/ C_{10-19}$ lyase in sheep adrenal homogenates (23). On the other hand, the apparent isotope effect observed in the present study, although small, is nonetheless significant; in fact, some steroid hydroxylations do not exhibit isotope effects (24). The detection of an apparent isotope effect reveals that $\mathrm{C}-\mathrm{H}$ bond cleavage for progesterone $16 \alpha$-hydroxylation may be one of the slow steps of the catalytic cycle, but one would need to determine the intrinsic isotope effect to evaluate the relative contribution of $\mathrm{C}-\mathrm{H}$ bond breaking to the overall rate (25).

The determination of the amount of tritium located at the $16 \alpha$-position by the use of mouse testicular microsomes has allowed accurate measurement of the apparent isotope effect. A tritium exchange method for progesterone $16 \alpha$-hydroxylation in the rat liver microsomal system was previously reported by De Graeve et al. (21), but these investigators did not determine the tritium distribution. Their hypothesis of an equal distribution of tritium between the $\alpha$ and $\beta$ positions at $\mathrm{C}-16$ is not valid in view of the known stereochemistry of the catalytic reduction of the corresponding $\Delta_{16}$ steroid. The determination of the apparent isotope effect is of obvious importance since the tritium release method has been employed in vitro and also in vivo to determine $16 \alpha$-hydroxylation activity toward various steroids $(26,27)$. In contrast to our results with progesterone, no kinetic isotope effect was seen in the $16 \alpha$-hydroxylation of several steroid estrogens by other investigators (28).

\section{ACKNOWLEDGMENTS}

This study was supported by Grant DK-10339 from the National Institutes of Health. Yoichi Osawa was a predoctoral trainee supported by Pharmacological Sciences Training Grant No. GM-07767 from the National Institutes of Health. The authors are grateful to Dr. Dennis R. Koop for providing $P-450$ form $3 \mathrm{~b}$ and for helpful advice, and to Dr. Anita H. Payne and Ms. Louise M. Perkins for the use of their facilities as well as for furnishing mouse testicular microsomes.

\section{REFERENCES}

1. Lu, A. Y. H., and Coon, M. J. (1968) J. Biol. Chem. 243, 1331-1332.

2. Lu, A. Y. H., and West, S. B. (1980) Pharmacol. Rev. 31, 277-295.

3. Coon, M. J., Koop, D. R., and Black, S. D. (1984) in Banbury Report, Vol. 16, Genetic Variability in Responses to Chemical Exposure (Omenn, G. S., and Gelhoin, H. V., Eds.), pp. 51-63, Cold Spring Harbor Laboratory, Cold Spring Harbor, New York.

4. Coon, M. J., Koop, D. R., Persson, A. V., and Morgan, E. T. (1980) in Biochemistry, Biophysics and Regulation of Cytochrome $P-450$ (Gustafsson, J.-A., Carlstedt-Duke, J., Mode, A., and Rafter, J., Eds.), pp. 7-15, Elsevier/North-Holland, New York. 
5. Koop, D. R., Morgan, E. T., Tarr, G. E., and Coon, M. J. (1982) J. Biol Chem. 257, 8472-8480.

6. Koop, D. R., and Coon, M. J. (1979) Biochem. Biophys. Res. Commun. 91, 1075-1081.

7. Johnson, E. F. (1980) J. Biol. Chem. 255, 304-309.

8. Koop, D. R., Persson, A. V., and Coon, M. J. (1981) J. Biol. Chem. 256, 10704-10711.

9. Johnson, E. F., and Schwab, G. E. (1984) Xenobiotica 14, 3-18.

10. Conney, A. H., Levin, W., Jacobson, M., Kuntzman, R., Cooper, D. Y., and Rosenthal, $O$. (1969) in Microsomes and Drug Oxidations (Gillette, J. R., Conney, A. H., Cosmides, G. J., Estabrook, R. W., Fouts, J. R., and Mannering, G. J., Eds.), pp. 279-302, Academic Press, New York.

11. Skett, P., and Gustafsson, J.-Å. (1979) in Reviews in Biochemical Toxicology (Hodgson, E., Bend, J. R., and Philpot, R. M., Eds.), Vol. 1, pp. 27-52, Elsevier/North-Holland, New York.

12. Dieter, H. H., and Johnson, E. F. (1982) J. Biol. Chem. 257, 9315-9323.

13. Johnson, E. F., Dieter, H. H., Schwab, G. E., Reubi, I., and Muller-Eberhard, U. (1982) in Cytochrome P-450, Biochemistry, Biophysics, and Environmental Implications (Hietanen, E., Laitinen, M., Hanninen, O., Eds.), pp. 283-290, Elsevier, New York.

14. Johnson, E. F., Schwab, G. E., and Dieter, H. H. (1983) J. Biol. Chem. 258, 2785-2788.

15. Osawa, Y., and Coon, M. J. (1985) Fed. Proc. 44, 1609.
16. Malaska, T., and Payne, A. H. (1984) J. Biol. Chem. 259, $11654-11657$.

17. Quinn, P. G., and Payne, A. H. (1984) J. Biol. Chem. 259, 4130-4135.

18. Malhotra, S. K., and Ringold, H. J. (1964) J. Amer. Chem. Soc. 86, 1997-2003.

19. Makino, T., Shibata, K., Rohrer, D. C., and Osawa, Y. (1978) J. Org. Chem. 43, 276-280.

20. Fieser, L. F., and Fieser, M. (1967) Reagents for Organic Synthesis, p. 142, Wiley, New York.

21. De Graeve, J., Kremers, P., and Gielen, J. E. (1977) Eur. J. Biochem. 74, 561-566.

22. Miyairi, S., and Fishman, J. (1985) .J. Binl. Chem 260, 320-325.

23. Osawa, Y., and Yarborough, C. (1985) Fed. Proc. 44, 632 .

24. Kupfer, D., Miranda, G. K., and Bulger, W. H. (1981) Anal. Biochem. 116, 27-34.

25. Lu, A. Y. H., Harada N., and Miwa, G. T. (1984) Xenobiotica 14, 19-26.

26. Pasleau, F., Kolodcizi-Mehaignoul, C., and Gielen, J. E. (1984) Endocrinology 115, 1371-1379.

27. Bradlow, H. L., Hershcopf, R. J., Martucci, C. P., and Fishman, J. (1985) Proc. Natl. Acad. Sci. USA 82, 6295-6299.

28. Milewich, L., MacDonald, P. C., Guerami, A., Midgett, W. T., Lassiter, W. L., and Carr, B. R. (1986) J. Clin. Endocrinol. Metab. 63, 180-191. 